Title: Statebuilding after disaster: Jiang Tingfu and the reconstruction of post-World War II China, 1943-49

\title{
Rana Mitter
}

University China Centre, University of Oxford, UK

\section{Rana.mitter@history.ox.ac.uk}

Total word count (main text, notes, abstract): 13,976 words

\section{Ten key terms:}

China, Jiang Tingfu, UNRRA, developmental state, Guomindang, rehabilitation, modernization, relief, postwar, Asia, Chinese Civil War

\begin{abstract}
:
Post-World War II reconstruction in Europe and Asia is a topic of growing interest, but there has been relatively little attention paid to the relief and rehabilitation effort in China in the immediate post-1945 period. This article reassesses the postwar programme implemented by the Chinese Nationalist (Guomindang) government and UNRRA (the United Nations Relief and Rehabilitation Administration) not just in terms of humanitarian relief, but as part of a process leading to new thinking about the nature of the postwar state in Asia. It focuses on the ideas and actions of Jiang Tingfu (T. F. Tsiang), head of the Chinese National Relief and Rehabilitation Administration which worked with UNRRA. Chinese ideas for reconstruction in China were simultaneously statist, international and transnational, shaped by high modern ideas drawn from Soviet and American examples. They were also influenced by China’s poverty and wartime vulnerability, which made locally-directed
\end{abstract}


solutions more relevant in areas such as public hygiene. Success was unlikely because of the incipient Chinese Civil War, and the huge demands of reconstruction on a state that was neardestitute and with destroyed infrastructure. However, its characteristics still bear examination as a first, tentative chapter in a longer story of post-imperialist and Cold War statebuilding that would shape countries in Asia and beyond. (209 words)

On 21 October 1949, Jiang Tingfu (T. F. Tsiang), then the Chinese ambassador to the United Nations, gave a speech at the US Naval War College in Newport, Rhode Island, on “The Problems of China.” Poverty, he explained, was at the heart of China’s long crisis of modernization. A whole variety of problems, including the failure to democratize, were attributable to China's continuous, crushing history of poverty.

Yet Jiang also saw signs that modernization might yet be on the way. "For the first time in one thousand years, the mind of China has returned to grain, plants and farm cattle, to water and soil, to coal and iron, to cotton, wool and silk, to brick and cement, to rivers, highways and railways. Before the beginning of World War II, there was a feeling of hope in China." ${ }^{1} \mathrm{He}$ described the way in which China had shifted from being an importer to an exporter of cotton in the 1930s, thanks in part to the adoption of more productive American cotton seeds. Jiang wrote of other agricultural improvements in the same era, in grain, rice, and irrigation.

One other factor, however, had exacerbated the longer-term debilitation. Agrarian reform, declared Jiang, had been stalled "because the war with Japan put a stop to all constructive

\footnotetext{
${ }^{1}$ Jiang Tingfu (T. F. Tsiang), “The Problems of China,” in Chen Hongmin, ed., Meiguo Hafo daxue Hafo Yanjing tushuguancang Jiang Tingfu ziliao ("The Tsiang Ting-fu Collection in the Harvard-Yenching Library, Harvard University, USA”) (24 vols., Guilin: Guangxi shifan daxue chubanshe, 2015), vol. 21, 528. Hereafter MHD.
} 
effort." He added, "I am afraid that some leaders in China used the war as an excuse for postponing reform.” But his main point was clear: “The war did come. It was real. It was gigantic. It did tax China’s human and natural resources to their utmost limit.”2

Jiang was speaking in the US at a moment when the regime that he represented was on the verge of collapse. Within months, a revolutionary insurgency with a much more radical version of agrarian reform would take power in Beijing, sweeping away the government that Jiang served, the Nationalist (Guomindang) regime under Chiang Kai-shek. Yet although the Nationalists were eradicated from the Chinese mainland, never to return, their brief period of postwar rule included an incipient framework for an alternative postwar settlement for China, with the intention of exercising influence in Asia more widely. In his speech, Jiang argued that his government had advocated plans for postwar relief in China as the starting point for a much more comprehensive process of agricultural and industrial reconstruction.

This article argues that the relief and rehabilitation effort in China in the immediate post1945 period should be re-examined, not just as an emergency programme, but as part of a process of international engagement with the creation of a new type of postwar state in Asia. The ideas that lay behind reconstruction in China were by turns statist, international and transnational. They were shaped by high modern ideas that were inspired in part by economic planning both of the New Deal and Soviet variety, but were also influenced by the reality of China's poverty and wartime vulnerability, which made "appropriate technology" relevant in areas such as public hygiene. ${ }^{3}$ The reality, as Jiang pointed out, was that the model of reconstruction was too ambitious to be realized. It made huge demands on a state which was not only near-destitute but also suffered hugely from problems of corruption and

\footnotetext{
2 Jiang, "Problems of China," 531.

${ }^{3}$ The classic statement on this is E. F. Shumacher, Small is Beautiful: A Study of Economics as if People Mattered (London, 1973).
} 
arbitrary authoritarianism. Postwar China proposed a model for itself and by extension, other postcolonial societies, without the capacity to fulfil such a model. But its characteristics still bear examination as part of a much longer story of post-imperialist and Cold War statebuilding that would shape countries in Asia and beyond.

The relative inattention to the reconstruction of postwar China stands in stark contrast to the parallel work on Europe, which has become a major subfield in modern European history. ${ }^{4}$ One primary narrative in that work is of a powerful actor, the United States, rehabilitating occupied powers in the context of an emergent Cold War with the Soviet Union. In recent years, the opening of Eastern European archives has enabled new work to emerge that shows a messier, less triumphalist reality in the eastern part of the continent. Another major theme has been the importance of international and transnational organizations in carrying out relief and rehabilitation. However, in Asia, as with the Cold War more generally, the idea of rehabilitation as a postwar, rather than postcolonial, phenomenon, has been less discussed until recently, the exception being the case of Japan, where the idea of the long sengo or "postwar" has for some years had significant scholarly currency. $^{5}$

Instead, a dominant narrative in understanding post-1945 Asia has been the rise of developmental, postcolonial, states, most notably South Korea and Taiwan. Another separate, South Asian narrative is the emergence of an independent India and Pakistan through the traumas of Partition in $1947 .{ }^{6}$ However, we still have only a partial history of China as a state debating and implementing postwar reconstruction and rehabilitation in the

\footnotetext{
${ }^{4}$ One recent point of entry to a growing literature is Mark Mazower, Jessica Reinisch, David Feldman, ed., “Post-War Reconstruction in Europe: International Perspectives, 1945-1949,” Past \& Present supplement 6 (2011).

${ }^{5}$ Carol Gluck, “The 'End' of the Postwar: Japan at the Turn of the Millennium,” Public Culture (Fall 1997)10(1).

${ }^{6}$ Yasmin Khan, The Great Partition: The Making of India and Pakistan (New Haven, 2007).
} 
period immediately after 1945, as opposed to reconstruction following the Communist revolution of 1949. China's status as a founder member of the United Nations Economic Commission for the Far East and Asia (ECAFE) in 1947 is one example of the way in which China's domestic experience of reconstruction shaped its international behaviour in the immediate postwar.

The idea and the reality of reconstruction were fundamentally shaped by the circumstances of what Jiang Tingfu termed the "gigantic" war with Japan. If the war against Japan (1937-45) had not taken place, China's developmental path would surely have been very different, perhaps more comparable with that of India. India's vision of postindependence vision of statebuilding was drawn in large part from the continuity with the pre-independence state, as well as change. Despite the terrible violence of the partition period, the majority of India’s infrastructure and territories were similar in form before and after 1947, even if they ended up divided. But in China, the immense physical destruction of factories, agricultural land, livestock, railways and roads during the war years created a fundamentally different landscape, one that in some senses resembled the devastation of Europe in $1945 .^{7}$ China, like France or Poland, was a "postwar" society in a way that India was not. But China, like India, was also a “postcolonial” society in a way that Europe’s liberated countries were not. It is this comparison, but also this difference, that explains the distinct path taken by reformers like Jiang who wished to reconstruct the country paying attention to both "posts", and by doing so, influence change not just in China but in Asia more widely.

\footnotetext{
${ }^{7}$ See Micah Muscolino, The Ecology of War in China: Henan Province, the Yellow River, and Beyond, 19381950 (Cambridge, 2015).
} 
The immediate postwar in China is also, of course, associated with the Chinese Civil War, which has been largely viewed through the lens of military history and elite politics. ${ }^{8}$ In this context, the conflict between an insurgent Chinese Communist Party (CCP) and an increasingly unviable Nationalist (Guomindang or Kuomintang) Party has been at the fore, with the major theme being the reasons for the eventual victory of the CCP. However, in recent years, a small but growing literature has begun to interpret the period in a new framework which reassess the socio-political programme of the Nationalist government. Tehyun Ma’s work examines the importance of transnational concepts of welfare and social security in shaping Nationalist ideas of reform in a postwar China, while Nicole Barnes has examined the way that hygienic modernity in the wartime era was used to reshaped gendered ideas of the state's role. ${ }^{9}$

These ideas largely fell victim to the lack of state capacity in Nationalist China. However, that lack needs to be seen in the context of a profoundly damaged state system. Reconstruction was, ironically, harder to implement in a country that was nominally a wartime ally with its own sovereignty, particularly after the signing of the 1943 treaties that ended extraterritoriality, than in a country that had either been wholly under enemy occupation or had been an enemy belligerent.

This reality means that the role of international organizations in shaping China's postwar deserves to be better understood, and in particular, the interaction between UNRRA (the United Nations Relief and Rehabilitation Administration) and CNRRA (the Chinese National Relief and Rehabilitation Administration). Rather than seeing the period solely as one in which international assistance came from outside to assist China, it should be

\footnotetext{
${ }^{8}$ A major study is Odd Arne Westad, Decisive Encounters: The Chinese Civil War, 1946-1950 (Stanford, 2003). ${ }^{9}$ See articles in European Journal of East Asian Studies 11:2, special issue on relief and rehabilitation in wartime China (December 2012).
} 
emphasized that international, transnational and local projects for modernization were part of a combined set of ideas. One of the most important figures to link these strands was Jiang Tingfu, a figure at once ambitious, principled, and flawed.

The article is divided into several sections. First, it details the role of Jiang Tingfu, the senior figure placed in charge of China's postwar relief and rehabilitation, and shows that his goals were dependent on his fractious relationship with the major body responsible for funding postwar reconstruction, the United Nations Relief and Rehabilitation Administration (UNRRA) and the Chinese partner organization which he headed, the China National Relief and Rehabilitation Administration (CNRRA). It then shows the problems of "scaling up" to the immense task that faced the agencies seeking to reconstruct postwar China, in particular the areas only recently liberated from the Japanese; these included a fundamental economic and financial crisis, embedded structural violence caused by fractured authority, and widespread health crises and malnutrition. The article argues that Jiang Tingfu’s ideas in shaping relief and rehabilitation in postwar China provide one of the first, tentative blueprints for what a sovereign Asian developmental state might look like, even if the national circumstances of the time made such ideas impossible in practice.

Jiang Tingfu, UNRRA and the international

Jiang was a figure in some ways symbolic, if hardly typical, of one section of China's Nationalist (Guomindang) elite. Born in Hunan province, he won scholarships that let him study in the US including a $\mathrm{PhD}$ at Columbia. He returned to China and took faculty positions at Nankai and Tsinghua universities, becoming well-known in the 1930s as a leading figures associated with Duli pinglun (“The independent critic”), a liberal journal that 
criticized Chiang Kai-shek’s Nationalist regime on a variety of political issues. ${ }^{10}$

Nonetheless, Chiang appointed Jiang as China’s ambassador to Moscow in 1936-38. He served in wartime China as president of the key government body, the Executive Yuan, before being sent to Washington DC. ${ }^{11}$

Jiang Tingfu’s political thinking developed significantly over his life. While his association with Duli pinglun has led to his characterization as a "liberal," his writings show a rather more complex ideological shift over time. He was always strongly anti-imperialist, and in 1936, even before the war with Japan broke out, Jiang argued that imperialism was economically unnecessary in the modern world: “There is no need to use political or military force to open markets. The US, Britain, and Japan do not do so when they trade with each other." ${ }^{2}$ He also argued that popular government might not be effective in modernizing society: "In China, Japan, Turkey and Russia, modernization has been top-down, and has often violated the popular will... From these four countries’ modernization process, we can obtain a common conclusion: countries where political authority is more centralized have a greater success in promoting modernization.”13

However, Jiang did grew gradually more hostile toward the Soviet and Chinese Communist models. He came deeply to admire the United States and Britain, and understood the advantages of pluralist democratic politics in a way that Chiang Kai-shek and other conservative figures in the Nationalist party did not. Jiang was always clear that state modernization was a complex process in which different parts of economy and society would

\footnotetext{
${ }^{10}$ On Jiang's political thinking, see Edmund S. K. Fung, The Intellectual Foundations of Chinese Modernity: Cultural and Political Thought in the Republican Era (Cambridge, 2010), 97, 134.

${ }^{11}$ One recent, detailed study of Jiang's life is Zhang Yulong, Jiang Tingfu shehui zhengzhi sixiang yanjiu (Research on the social and political thought of Jiang Tingfu) (Beijing, 2008).

12 Jiang Tingfu, "He wei diguozhuyi?” (What is meant by imperialism?), speech originally delivered 13 April 1936, in Jiang Tingfu, Jiang Tingfu xuanji (Selected works of Jiang Tingfu) (Taipei: Zhuanji wenxue chubanshe, 1978), 629. Hereafter, JTF.

13 Jiang Tingfu, “Zhongguo jindaihua de wenti” (The problem of Chinese modernization), originally in Duli pinglun (1937), JTF, 640.
} 
need to be brought together. In the 1930s, the Nationalist government had begun to plan for a wartime economy under the National Resources Commission. ${ }^{14}$ Jiang was particularly affected by his visit to one particular project in 1944 :

Three years ago, when I was visiting the Tennessee Valley Authority, I found that there were many technicians and managers who were willing to receive relatively low wages and carry on working... They were not willing to take posts there if it became a private company, even if the company could then pay them several times more remuneration. They felt that the pleasure in the work and the social relevance was their greatest reward. Although the TVA could not make them into rich men, it could satisfy all their most appropriate desires. ${ }^{15}$

This was a rose-tinted view of the TVA, to put it mildly, but Jiang's intended readership was politically engaged Chinese, not Americans. He expanded further, making it clear that he saw a clear link between public service, state infrastructure provision, and a sense of national moral uplift:

If our intellectuals here can preserve the traditional spirit of the scholar-officials, we can do better than the past 300 years of western history. Sun Yatsen promoted nationalism, people’s rights, and people's livelihood all at the same time, as he wanted to shorten the historical process [of modernization]. Now the enterprises that engineers are carrying out in China are shortening that historical process somewhat. What we can achieve in terms of systems and mechanics, we ought also to be able to achieve in terms of morality. ${ }^{16}$

\footnotetext{
${ }^{14}$ William C. Kirby, “The Chinese War Economy,” in James C. Hsiung and Steven I. Levine, ed., China’s Bitter Victory: The War with Japan (Armonk, 1992), 192-4.

15 Jiang Tingfu, "Mantan zhishifenzi de shidai shiming” (Discussing the contemporary destiny of the intellectuals), originally in Shiji pinglun 1:24 (14 June 1947), JTF, 672.

16 “Mantan zhishifenzi," 672.
} 
These words were written in 1947, after the main UNRRA programme had concluded in China. Yet the links between scientific modernity and national morality had always been central to Jiang's world-view, and his understanding of what postwar modernization was supposed to look like. Jiang's vision for dealing with the devastation caused by the Japanese invasion of China was not merely one which sought to patch up the damage, but rather a model that drew on existing development practice in China and create a Chinese state that was overall more developed than it had been before $1937 .{ }^{17}$ Jiang was an emergent Cold War liberal, an enthusiast for a large state that could develop his ideological preferences of being anti-Soviet and pro-development.

\section{Launching reconstruction}

In late 1943, the United Nations Relief and Rehabilitation Administration was established, and Jiang was chosen as the Chinese delegate to its Council. While still in Washington, Jiang proposed a revision to the UNRRA plans, arguing for greater commitment to improvements in medicine, transportation, and social welfare. In September 1944, Jiang made a request for US\$945 million of imports (about 40 per cent of China’s needs), with the services of 2200 foreign experts. At the time, many of the UNRRA Council members felt that China's demands were too high. ${ }^{18}$ However, the analysis of UNRRA's official historian just three years after the programme’s closure was less critical of Jiang’s request: “The supply estimates... were moderate, considering the enormous need of the areas, occupied or

\footnotetext{
${ }^{17}$ On prewar development, see Margherita Zanasi, "Exporting Development: The League of Nations and Republican China,” Comparative Studies in Society and History (49:1), January 2007.

${ }^{18}$ Zhang Yulong, Jiang, 236-9. George Woodbridge, ed., UNRRA: the History of the United Nations Relief and Rehabilitation Administration (Columbia University Press, 1950), vol. 2, 376-7.
} 
dominated by enemy forces, which they were intended to meet, but they far exceeded, in most categories, what UNRRA was able to devote to the China program.”19

On return to China, Jiang Tingfu was appointed as director-general of the new Chinese National Relief and Rehabilitation Organization (CNRRA), the sister organization to UNRRA, established by the National Government. He would serve as its leader from January 1945 to October 1946 (when he would resign, to be replaced by P. H. Ho). Its structure would grow over the next few years. During its period of operation (1943-7), UNRRA/CNRRA in China would have over 30,000 employees, a headquarters in the wartime capital of Chongqing, which then moved to Shanghai and Nanjing, fifteen regional offices, six main supply offices, and several specialist field units. It would liaise with the Ministry of Communications, which was in charge of railway and road rehabilitation, and with the Ministry of Water Conservancy for problems of floods and irrigation. CNNRA obtained its internal financing through the Executive Yuan of the Government, the Ministry of Finance, and the Central Bank of China. It would also liaise with the CCP-run CLARA (Chinese Liberated Areas Relief Association), which was represented in Shanghai, with major offices in Tianjin and Kaifeng. ${ }^{20}$

Over the course of the programme, the total of goods supplied by UNRRA to China was valued at US\$517.85 million, consisting of 2.4 million tons of materials. (See Table 1 for full details).

Table 1 - Total UNRRA deliveries to China, 1944-47 21

US dollars

\footnotetext{
${ }^{19}$ Woodbridge, UNRRA, 376-7.

${ }^{20}$ Woodbridge, UNRRA, 374. Zhang, Jiang Tingfu, 240.

${ }^{21}$ From Table 38 in Woodbridge, UNRRA, 378.
}

gross long tons 
Food

$131,789,900$

Clothing, textiles, footwear $\quad 112,530,900$

Medical/sanitation

Agricultural rehabilitation

Industrial rehabilitation

- Total
$32,717,200$

$71,676,600$

$169,132,100$
$1,091,617$

169,339

41,024

395,014

663,921

In his initial period in office, Jiang found himself intervening directly with Chiang Kaishek to ask for more relief materials to be added to the small amounts assigned to flights across the Burma Hump. ${ }^{22}$ Even before the end of the war, UNRRA noted that there was a “serious shortage of food in the liberated areas” (referring to Guizhou and Guangxi). ${ }^{23}$ Then the war came to a sudden end in August 1945, and UNRRA's officials confirmed the urgency of the situation:

Overnight, with coming of peace in Asia, the relief needs of China become of compelling urgency. This relief, too, must be brought rapidly over the entire area of occupied China, instead of piecemeal - as was planned - as liberation moved slowly from one area to another. ${ }^{24}$

This report, in the days immediately after the ending of the war, calculated the total request from the Chinese government at 10 million tons of supplies, priced at some $\$ 3.5$

\footnotetext{
${ }^{22}$ Zhang, Jiang Tingfu, 251.

${ }^{23}$ William J. Green, Agricultural Rehabilitation Officer, 25 June 1945.

${ }^{24}$ UNA S-0528-0053 (China weekly reports, 1944-45), E. T. Nash report on "UNRRA and its plans for China" (21 August 45).
} 
billion, of which they hoped that 4 million tons (worth $\$ 1$ billion) would be supplied by UNRRA. However, the report noted that "severe limitations of available supplies, finances, and transportation, as well as the balancing of servicing among the claimant countries” made it unlikely that China would receive all that it asked for. ${ }^{25}$

The end of the war gave Jiang a new opportunity to ask for further supplies, and in October 1945, he called for 2 million tons more to be sent to China. "The coming winter is going to be terrible,” he declared in a speech in October 1945, “and unless we can obtain UNRRA assistance, then the suffering will be terrible, and next year's relief and rehabilitation problem will be worse.”26

\section{A plan for postwar China?}

However, the messy reality of China’s late wartime and postwar should not obscure the distinctive elements of the polity that the Nationalist government was attempting to create. The western Allies had created a strengthened welfare state in their own societies (the Social Security Act and G.I. Bill in the US, the Beveridge Report in Britain); Tehyun Ma has written about the way in which such plans influenced Nationalist Chinese political thinking in the late war years. ${ }^{27}$ The USSR reconstructed with a new domestic emphasis on the command economy and wider planning. The first tranche of states to gain independence from Britain, India and Pakistan, were constituted as parliamentary republics.

China sought to create, or "reconstruct” a rather different sort of polity. This state would participate internationally in the liberal, non-communist part of the American-

\footnotetext{
${ }^{25}$ Nash report, "UNRRA."

${ }^{26}$ Zhang, Jiang Tingfu, 251.

27 Tehyun Ma, "'The Common Aim of the Allied Powers": Social Policy and International Legitimacy in Wartime China, 1940-47’, Journal of Global History 9:2 (2014).
} 
sponsored international order, yet significantly constrain liberal political change at home, at the same time as engaging with issues of social welfare. China was one of a very small number of extra-western polities, even in 1945, to have relatively free agency to design its state without a clear external veto, albeit within the very real constraints of badly damaged national finances and crippling war damage. The Nationalists chose to create a state with a partially democratic constitutional assembly, led by a vanguardist party that pledged a limited level of social reform. They could be accused, not without justice, of redesigning their politics to try and suit an American idea of what a Chinese democracy might look like. But this explanation fails to take into the account the indigenous influences on politics that had moved China in the wartime years much more strongly toward the politics of a command economy, popular mobilization, and nationalist sentiment. For Jiang Tingfu, relief and rehabilitation would bring these ideas together, not only to deal with immediate war damage, but also to create the kind of modernized China that he had hoped for in the 1930s, but which had been violently thrown off track by the war with Japan.

In an interview in Zhongyang ribao on 8 December 1945, Jiang gave a clear sense of the plan he envisaged for UNRRA and CNRRA to combine immediate relief with longerterm rehabilitation. The scope and timescale ranged from the very immediate to the longerterm. He advocated the establishment of temporary relief centres in centres including Kunming, Guiyang, Yichang and Xi'an to cope with his estimate of some 42 million refugees, as well as a wider distribution of soup kitchens and medical centres. He further proposed reconstruction of public hygiene facilities, railways, schools, hospitals, and agricultural production. In addition, he suggested that UNRRA materials could be used to stabilize markets and prices. ${ }^{28}$

${ }^{28}$ Zhongyang ribao (8 Dec. 1945), cited in Zhang, Jiang Tingfu, 253. 
In a later article from 1946, entitled "What is UNRRA, and what is it going to do?”, Jiang differentiated between "relief” [jiuji] and "rehabilitation” [shanhou]. The first, he felt, was short-term, with "humanitarianism” [rendaozhuyi] at its core, whereas the latter was “long-term and positive,” with “progress and development” at its heart. He went on: "rehabilitation is the best and most positive form of relief," adding "relief on its own cannot solve our economic problems." Indeed, blind faith in "relief," he suggested, might be “society’s most unwise move.”29

Jiang argued that dealing with immediate problems of relief should not stand in the way of engagement with more detailed problems of infrastructure. The reconstruction of shattered cities might involve rebuilding destroyed houses, supplying food, rebuilding transport links, and reconstructing commercial networks. Yet China’s economy was in no state to afford such a programme; Jiang estimated that the country’s entire relief budget might support at best five per cent of the population. Therefore, infrastructure building should become a priority. As an example, he gave the reconstruction of the Tianjin-Pukou (Jinpu) railway that linked northern and east-central China. UNRRA help would be needed to pay the workers' wages, but the investment would provide much-needed infrastructure and jobs. The workers might be able to supply food themselves, but their wages would go toward the repair of their houses, the purchase of tools, plants, etc.

Jiang laid particular stress on agricultural rehabilitation, knowing that China’s economy would be highly dependent on its rural economy reviving, and aware that human and animal power, rather than mechanization, would be most immediately relevant to postwar China. Among his suggestions was that UNRRA should supply some 100,000 water-buffalo from India. Jiang confirmed the priorities of the UNRRA administrators about continuing

\footnotetext{
${ }^{29}$ Jiang Tingfu, “Shanhou jiuji zongshu: gan shenme? Zenme gan?” (UNRRA: what should it do, and how?), in Zhang, Jiang Tingfu, 242.
} 
the programme of rural hygienic modernization: "investment in the enterprise of hygiene is, we believe, the greatest investment, the best return.” Jiang also saw the UNRRA programme as a means of controlling the chronic inflation that plagued China during its war years.

Funds were needed for emergency relief, but also for rehabilitation through the provision of wages (whether as cash or in kind as food or clothing, the latter in part to prevent too much cash being distributed, which might fuel inflation). ${ }^{30}$

UNRRA acknowledged the priorities laid out by Jiang. In the organization’s official history, published in the immediate aftermath of the programme’s closure, it was acknowledged that more was given to China for rehabilitation "than in most of the European countries," because of the National Government's view that "fundamental recovery from the war would be most effectively promoted in China if substantial efforts could be made to revive internal transport, production, and trade, as well as to furnish urgently needed war relief to war sufferers.”31

Jiang recognized that UNRRA aid would be sent to areas controlled by the CCP, making it clear that he believed in "no discrimination on the grounds of political belief or race.” ${ }^{32}$ Yet overall, the Communist areas received a very small proportion of the total supplied by UNRRA. The official history declared that CLARA received only about 3 per cent by weight or 4-5 per cent by value of the shipments because "they had no serious food shortage except in small local pockets” and they could supposedly not use the heavy industrial material that was a large part of the shipments. "No attempt was made to calculate, theoretically, what might have been a wholly equitable percentage of goods for the

\footnotetext{
${ }^{30}$ Jiang, “Shanhou jiuji,” in Zhang, Jiang Tingfu, 243, 244-5.

${ }^{31}$ Woodbridge, UNRRA, 377.

${ }^{32}$ Zhang, Jiang Tingfu, 245.
} 
people in Communist areas.” But, the history acknowledges, had anyone done so, the proportion would have been higher than what was actually supplied. ${ }^{33}$

\section{Aspirations and reality}

Jiang might have admirable aspirations for the reconstruction of China, but any such plans could not possibly have been carried out by a government on the verge of financial collapse. The commitment of UNRRA to the work of reconstruction was therefore a boon for his plans.

For most of UNRRA’s period in China, its country director was Benjamin H. Kizer (October 1944 to May 1946); he was followed by J. Franklin Ray, Jr (acting); Maj. Glen Edgerton (August 1946 to April 1947), and Harlan Cleveland (May 1947 to the end of the programme). The relationship between Kizer and Jiang, and their respective staffs, would shape the joint UNRRA/CNRRA agenda. Essential though it was in terms of bringing funding and expertise, the UNRRA presence in China had the potential to cause friction when it encountered the strong sense among many Chinese political actors that their country ought to be able to shape its own postwar destiny. By 1943, when UNRRA was established, China was a formal ally of the United States and Britain, in which role it made its anti-imperialist views clearly known. The former treaties which had permitted the system of extraterritoriality had been abandoned earlier that year. China was in an unusual position in that it was neither a conquered nor occupied state, yet it did not have the resources of the

\footnotetext{
${ }^{33}$ Woodbridge, UNRRA, 389.
} 
other major Allied belligerents to dictate the shape of the postwar environment on its own terms. $^{34}$

Discussions within the UNRRA leadership showed continuities with the pre-war advisers from the League of Nations, who had played an important role in creating a developmental framework within China. ${ }^{35}$ Part of the dilemma as to the appropriate role for postwar China was expressed in correspondence between administrators who debated whether China should be a contributor to the overall UNRRA budget, not just for financial reasons but also to provide a clear indication of China's commitment to the agency, and by extension, to the wider emergent international order. ${ }^{36}$

Harry B. Price, Assistant Director for the UNRRA China Office, wrote to Edwin G. Arnold of the Deputy Director-General's office in Washington that Jiang Tingfu wanted to settle questions of responsibility for relief, procurement and technical assistance, among other issues. Among Jiang's key demands was the Chinese government agency, CNRRA, should be in charge of distribution of resources, although UNRRA should organize technical requests, subject to Chinese government request. At the meeting, Price had mentioned “Chinese ability to pay, or China’s position as a contributor or non-contributor.” He went on to argue, in a personal comment on 31 December 1944,

On further reflection, my own mind has become more open on this question. The extremely low standard of living, the ravages of the war, and China's relatively small foreign exchange assets in relation to her population or to the gigantic tasks of

\footnotetext{
${ }^{34}$ For postwar Chinese diplomatic planning, see Xiaoyuan Liu, A Partnership for Disorder: China, the United States, and Their Policies for the Postwar Disposition of the Japanese Empire, 1941-1945 (Cambridge, 1996).

35 Zanasi, "Exporting Development."

${ }^{36}$ UNA S-0528-0032 (Correspondence, Chungking to Washington DC headquarters, 1944-1949), Price to Arnold, 31 Dec. 1944.
} 
reconstruction to be faced after the war, all seem to point to the reasonableness of according to China a status of non-contributor.

He then posed an alternative way of considering the issue:

On the other hand, if China contributed a portion of her foreign exchange assets to UNRRA, would the psychological effect upon the Chinese people and Government be better than if she got something for nothing? Would UNRRA's operations in China be subject to less criticism among the contributing countries? Would a contribution by China tend to make the whole relief and rehabilitation operation a more serious and earnest one on the part of the Chinese government? And would such a utilization of a part of her exchange resources actually contribute to an attitude abroad of greater willingness to invest funds in China for the reconstruction period, and thus result in a net gain for China?

He concluded: "It may be that China's grave economic and financial problems and limited resources will preclude the possibility of her becoming even a partial-contributor, but the question appears to demand rather searching analysis in the light of all available facts before definite conclusions are reached.” He went on to add, with some foresight about arguments that would spring up after the war:

Incidentally, if China were to contribute a share to UNRRA, it might lessen criticisms which might otherwise develop should China prove unable to undertake an internal contribution to relief and rehabilitation on the scale envisaged in the program presented to UNRRA. ${ }^{37}$

\footnotetext{
${ }^{37}$ UNA S-0528-0032 (Correspondence, Chungking to Washington DC headquarters, 1944-1949), Price to Arnold, 31 Dec. 1944.
} 
Price added that press coverage of China needed a "deeper historical perspective, a better understanding of China's problems and people, and a greater disposition to deal with facts rather than hearsay.” This was prompted, no doubt, by the largely negative view of Nationalist China to be found in the US press at that moment: Time magazine’s assiduous correspondent Theodore White had covered the rapid defeat of Chinese troops in central China during the Japanese Ichigo campaign that had begun in spring 1944, as well as the recall of General Joseph Stilwell in October 1944, which was portrayed as a victory for Chiang as a capricious dictator over a dedicated American career soldier. ${ }^{38}$ At that point, it seemed likely that China might collapse militarily before the war in Asia could be ended, which would render moot the question of the country's postwar reconstruction under the Nationalists.

However, Price had been right to see that the "searching analysis" to which he referred was at the heart of the wider issue that haunted the question of China's role within UNRRA: should it be seen as a supplicant or a participant, particularly in light of the heightened position that it now occupied in the new global order at the United Nations and elsewhere? From the Chinese point of view, however, the question was phrased rather differently: what rewards did China have a right to expect, having made immense sacrifices as the first Allied actor in the Asian theatre?

Jiang made the latter case clearly at a speech given in Washington DC in January 1949 where he argued that "the long war against Japan” was the primary cause of China's immediate agricultural crisis. He turned the accusation specifically against his American listeners:

\footnotetext{
${ }^{38}$ See Hans J. Van de Ven, War and Nationalism in China, 1925-1945 (London, 2003), ch. 1.
} 
People in the United States do not have the least knowledge of the meaning of this long war in terms of human misery in China... We fought Japan by deepening our misery. That went on for eight long years. This burden of war-born misery added to the centuries-old misery was simply too much. ${ }^{39}$

Jiang acknowledged the failings of the Nationalist government ("the Government, by adopting wiser measures during the war, might have lessened the misery of the people by a small percentage") but he insisted nonetheless that "with the best wisdom in the administration, the Chinese people would, nevertheless, come out of the war in a very pitiful condition." ${ }^{40}$ The prospect of an immediate collapse in China lessened after the Ichigo campaign halted in early 1945, and political and military relations improved somewhat with the appointment of General Albert Wedemeyer to replace Stilwell. Jiang Tingfu and Benjamin Kizer held regular meetings during the initial period of coordination between UNRRA and CNRRA. During the meeting of 7 February 1945, Jiang was clear that he wanted to draw up lines of control between UNRRA and the Chinese government, and was clearly prickly about their presence in China. (This was, after all, the scholar who had written in scathing terms about imperialism and its effects less than a decade earlier). Jiang wished to know if other countries had UNRRA offices set up in a similar structure to the one in China (a moot question, as no other sovereign country had quite the same form of UNRRA presence as China); was clear that he disliked elements of the directive for the China Area Office; and was insistent that the office must not be seen to encroach on the privileges of the Chinese government. He expressed further discomfort at the idea that UNRRA might “establish” new programmes, try for an "invasion of his authority,” and "no foreign voluntary relief agency now conducts operations within China without the consent of the Chinese

\footnotetext{
${ }^{39}$ Jiang Tingfu, “The Situation in China” (speech to Republican Club, Washington DC (?), 14 Jan. 1949), in MHD vol. 21, 511.

${ }^{40}$ Jiang, "Situation,” 511.
} 
government.” Jiang had wanted a paragraph declaring that UNRRA employees would "not... criticize any department of the Chinese Government or in any other way... interfere in Chinese politics.”41 Kizer declined to offer such an assurance in writing, but provided alternative phrasing, reassuring him that the agency had no independent aims of this sort.

UNRRA, rather like the SCAP (Supreme Command for Allied Powers) administrators during the occupation of Japan, was staffed by large numbers of progressive internationalists. Their dedication to their work was beyond question, and their understandable scepticism of the Nationalist government came from observation of the corruption and waste that was undoubtedly a significant part of UNRRA's presence in China. However, the correspondence between Price and Kizer illustrates a recurring problem that lay at the heart of the interaction between Jiang and UNRRA. Jiang's claim to Chinese autonomy on reconstruction was, in the end, a moral one: that the country had contributed to the defeat of Japan, and therefore should be given special status when it came to reconstruction. In his 1949 speech on "The Problem of China," he declared:

For eight long years Free China used the western part and less developed half of the country as a base to fight against Japanese invasion and blockade. The world has not begun to understand the economic meaning of that long war and blockade... This economic aftermath of the war indeed served as fertile soil for the growth of communism in China. ${ }^{42}$

Jiang's concession of error on the part of the Nationalist government is only partial, but significant, because he was in service to that same government at the time he made his remarks. He was taking advantage of his status as a liberal figure who was valuable in

\footnotetext{
${ }^{41}$ UNA S-0528-0032 (Correspondence, Chungking to Washington DC headquarters, 1944-1949), Kizer to M. Menshikov (UNRRA Deputy Dir. - Gen.), 7 Feb. 1945.

42 Jiang, “Problem,” 531.
} 
making the Nationalist government better-regarded in the US at a time when the former was close to collapse, but his criticism was notable for its consistency in these postwar years: he placed blame for specific issues on the shoulders of Chiang's regime but insisted that the devastation caused by the war itself was the major factor in holding back China's development. Of wartime China, he declared:

She could have done better, but not much better. In the first place, in western China, which was Free China, industry has not been developed to any high degree. There was very little wealth for the government to tax... Most farmers grew the food for the consumption of their own families... Meanwhile, inflation has wiped out the whole middle class... Some criticize Generalissimo Chiang Kai-Shek as shouldering the chief responsibility. Leaders do have their responsibility, but I submit that an objective study of the total situation in China would declare that the sad plight of China today is mainly the result of the war, on top of a poverty, which was deeprooted, vast and old. ${ }^{43}$

In his January 1949 Washington speech, Jiang criticized the UNRRA project largely on the grounds of comparative size. He noted that the total amount spent in China was some US\$600 million (\$571.8m according to the official UNRRA history):

It is a very big figure, but it is only about as big as the amount spent by UNRRA in Italy, not much more than the amount spent in Greece or Poland. The per capita relief in China amounted to less than one dollar and a half, while the per capita relief in Eastern and Southern Europe averaged more than twenty-five dollars. Relief by UNRRA alone has been found insufficient to stem the tide of communism in either

43 Jiang, "Problem,” 532. 
Greece or Italy. Much more has been done for both these countries since UNRRA closed its doors. $^{44}$

He reiterated the point in his speech in October of that year:

UNRRA spent in China altogether US\$670,000,000.00 [sic]. It was a big sum. Seventy per cent of this sum came from the good people of this country; Great Britain, Canada, Australia, India and several Latin-American countries, notably Brazil, all contributed... But the per capita relief in China, as compared with the per capita relief in Poland, Czechoslovakia, Ukraine, and Greece is equivalent to one to thirty. It was extremely meagre. ${ }^{45}$

One purpose of Jiang's complaint was to distract attention from a chaotic and corrupt governmental structure. Yet UNRRA's own official history, published just five years after the end of the war with Japan, admitted that there was still justice in his argument, suggesting that it was simultaneously true that a very great deal had been done for China, and that it was not enough: “Although not commensurate with the nation's vast needs and less in relation to the population affected than the European aid programs, the UNRRA program for China was more extensive than any comparable effort ever previously undertaken on behalf of a single nation. “46 In the end, the question of payment was settled with a decision that UNRRA should provide supplies, and CNRRA (in effect, the Chinese government) should deal with its distribution and processing. The total cost of financing the Chinese part of the programme was estimated at US\$190.9 million in 1947 dollars (calculated at CN\$405.6 million in pre-war, pre-inflationary Chinese currency). The figures are approximate in part, but the official historian believed that "they are sufficiently accurate... to indicate that the

\footnotetext{
44 Jiang, “Situation,” 512.

45 Jiang, "Problem," 532.

${ }^{46}$ Woodbridge, UNRRA, 371.
} 
cost of assimilating the UNRRA program in China was 35-40 per cent of the estimated value of the UNRRA supplies." ${ }^{47}$ In other words, China's contributions to the cost of the programme were not trivial, and these costs place in some perspective the often justified accusations of graft and corruption.

\section{Hygiene and reconstruction}

Much of the Nationalist government's portrayal of itself as a politically progressive force ("Free China”) during the war years was an attempt to woo American public opinion at a time when stories of dysfunction and corruption in China were seriously tarnishing the country’s image. Yet recent research has also showed that there had been significant developments in the provision of public services in wartime China, many of which were undertaken in the expectation that they would lay the foundation for a reconstructed postwar China. ${ }^{48}$ In particular, the state made significant efforts to implement reform in areas of public health and hygiene. This tendency emerged well before the war began; Ruth Rogaski has written of the importance of "hygienic modernity” in shaping China’s nationalism and modernization in the early twentieth century. ${ }^{49}$ During the war, the discourse of New Life and rejuvenation went hand in hand with a series of measures relating to health. Sichuan province, which was one of the areas most securely under Nationalist rule, was one of the most important sites for new social programmes. Chongqing, as the temporary capital, was a central focus of much experimentation in public health.

During the last years of the war, Chongqing and the areas of Sichuan where the Nationalist government broadly had control were required to engage with different forms of

\footnotetext{
${ }^{47}$ Woodbridge, UNRRA, 399-400.

${ }^{48}$ See essays in European Journal of East Asian Studies 11: 2 (2012).

${ }^{49}$ Ruth Rogaski, Hygienic Modernity: Meanings of Health and Disease in Treaty-Port China (Berkeley, 2004).
} 
hygienic improvement. In March 1944, the Sichuan provincial government hygiene office received orders from the central government that obstetrics should become a top priority. "Having started in experimental counties in and near Chongqing, the programme will be expanded to the whole of Sichuan province," the provincial authorities were told. ${ }^{50}$ Other orders encompassed a wider agenda of hygienic modernity for the temporary capital: "Deal with cleaning roads, garbage processing, wastewater, improving drinking water, toilet improvement, and tidying up the appearance of the city.” The programme also included ambitious proposals to clean houses, maintain nurseries and schools in a hygienic condition, and collect information on the nutrition level of the population. Mobile clinics ought to be converted into fuller-service hygiene centres, and there should be one such centre for every five county towns. ${ }^{51} \mathrm{~A}$ further edict declared that an experimental factory district should be set up as a "hygiene district," and workers should be employed in the patriotically-defined task of “cleaning toilets for national purposes,” as well as carrying out wider community environmental improvement. Citizens ought to be made to pledge to a "household cleaning system,” which should be underpinned by motivational activities, including using meetings and market day gatherings to propagandize for hygiene, and carrying out spot checks, along with "hygiene competitions." Offenders could be fined. Finance for these activities was rather less assured: advice came that the authorities could "borrow from other budgets," or else solicit donations. ${ }^{52}$

The programmes of hygienic modernization in Chongqing were an indication of intent, but they ran up against the reality of a shattered infrastructure, a blockaded country into which only limited supplies could be flown, and deeply limited state capacity, as well as

\footnotetext{
${ }^{50}$ Sichuan Provincial Archives (113-6: Minguo 30-33/1941-44), "Zhongyang weisheng shiyanyuan ...banfa”) (Methods... of the central government hygiene experimentation institute), " correspondence (March 1944).

51 “Zhongyang weisheng”, correspondence (March 1944).

52 “Zhongyang weisheng”, correspondence (March 1944).
} 
the limitation that the Nationalists controlled only a part of the country. There were two means of addressing the crisis. One was to find "appropriate technology" to provide some form of meaningful reform at low cost. The other was to use the funds provided by the new international organizations, in particular UNRRA, to fulfil developmental goals.

During the war itself, concentration was necessarily on what was possible, rather than most desirable. Large-scale surveys by UNRRA in the immediate postwar would demonstrate that parts of China that had been occupied were suffering from severe malnutrition by the end of the war. However, to address large-scale food security issues was not within the power of the Chinese government before the end of the conflict (which both UNRRA and the Chinese government had not expected to happen as early as summer 1945). These restrictions meant that, for instance, outside the major city of Chongqing, in rural counties where there was little infrastructure, there was more attention to locally feasible hygiene work. In various of Sichuan’s counties, reports of rehabilitation work were submitted which detailed more modest but important goals, many based on the provision of clean water and the maintenance of local toilets. In one county, local officials concentrated on "keeping the well clean, preventing people washing their vegetables in it, and keeping a lid on the well.” In the same county, they had closed down one noisome toilet, improved six, and built four new ones. Similar records came in from other counties. In Huayang county, it was noted that the inhabitants had no wells, and consequently drew their water from the river. However, because the river was polluted with garbage, they were advised to go upstream a little way to collect their water. They had also built five toilets to add to the existing 25, improved the overall levels of disinfection in the county, and undertaken forty-one "toiletimproving activities.” In Zhongjiang county, all public and private wells had been covered over, and the minority of people with no fence around the well were ordered to build one. Eight noisome toilets had been shut down, and doors placed on public toilets. In Pi county, 
82,015 buckets of disinfectant had been used on 41 exercises in hygiene; fourteen new toilets were set up, with 57 existing facilities being sterilized; and a long list of diseases were treated. ${ }^{53}$

Jiang Tingfu commented some years later on the way that health and hygiene issues had been developed during the war:

It was the National Government which established, for the first time in Chinese history, a national health service. This service, though understaffed through the eight years of war with Japan, was nevertheless able to prevent any epidemic in China. ${ }^{54}$

Jiang's phrase "national health service” was perhaps meant to bring to mind the British Attlee Labour government (1945-51) which he admired ("now the Labour Party in Britain, using free democratic means, has taken authority,” he wrote in 1947). ${ }^{55}$ In practice, "service” was too grandiose a term to describe a patchwork of facilities that had come together often under improvised circumstances. More accurate, and perhaps more suited to the reality of China's wartime situation, was the combination of a limited amount of classic high modernity (such as the building of urban hospitals) with a concentration on behavioural change and appropriate technology.

\section{Finance and planning}

During the war, a core problem for the National Government was the severe lack of funding for social programmes and rehabilitation. There was significant, if never lavish,

\footnotetext{
53 “Zhongyang weisheng,” correspondence (March 1944).

${ }^{54}$ Jiang Tingfu, “The Far Eastern Crisis” (speech given at the Indianapolis English Speaking Union, 1 March 1951), MHD, vol. 21, 553.

55 Jiang TIngfu, Zhengzhi ziyou yu jingji ziyou ("Political freedom and economic freedom”) (orig. Shiji pinglun, 26 April 1947), in JTF, 665.
} 
financial support for China from the United States from before Pearl Harbor, formalized as Lend-Lease after the US entered the war. However, this funding was intended to boost China's war effort, not fundamentally to reconstruct its social fabric. In addition, inflation, caused in large part by the Nationalist regime’s decision to print money and devalue the currency, reduced the value of the spending that did take place. The arrival of UNRRA meant the implementation of a programme specifically to address the immense damage the war had inflicted on China more broadly, rather than dealing with military crises. Its beginning coincided with one of the bleakest periods in the war in China, the last major assault by Japanese troops against Nationalist Chinese positions in the Ichigo campaign of 1944. Areas which had suffered terribly during the campaign, such as the city of Hengyang in Hunan province, would become areas of major concern for UNRRA in the postwar period.

Jiang was clear about the aims of the relief and rehabilitation programme. However, neither he nor the UNRRA administrators were initially able to assess the scale of the crisis that awaited them once the war was over. On 27 July 1945, Price told Arnold that there was only "fragmentary" intelligence on what was happening in occupied China, but that UNRRA was aware that there were particular crises in store in Guizhou, Hunan, and Guangxi provinces, with significant problems also evident in Fujian, Guangdong, Zhejiang, Jiangsu, and Shandong. ${ }^{56}$ The nature of the crises was similar to that which had preoccupied Nationalist wartime planners: disease control, health and hygiene, and the desperate need for agricultural and industrial rehabilitation.

The atomic bombings of Hiroshima and Nagasaki brought the war in Asia to a sudden end in August 1945. The task of postwar reconstruction moved from being a prospect some two or more years away to an immediate, urgent priority. In the words of Harry B. Price,

\footnotetext{
${ }^{56}$ UNA S-0528-0053 (China weekly reports, 1944-45), Price to Arnold (27 July 1945).
} 
who issued a major report titled "Immediate Problems of Relief and Rehabilitation” on 23 August 1945, just a couple of weeks after Japan’s surrender, “Capitulation of the Japanese has greatly hastened the need of relief and rehabilitation over a very wide area.”57 Price asked whether the OSS and Chinese army could provide further data on which to make judgements. However, the immediate aftermath of the war allowed snapshots to be taken of the state of the occupied areas. He categorized the major areas of concern under sixteen headings: intelligence (and the lack of it) about local conditions; supply, and the need for a clear picture of what resources were available; shipping; supply and transportation services; allocation of goods (and the creation of authority to do this); distribution of relief supplies; health and medical relief; work relief projects; the restoration of utilities; the rehabilitation of transportation; the rehabilitation of industries; the rehabilitation of agriculture and fisheries; the provision of personnel to staff programmes; the establishment of a more robust overall organization for relief and reconstruction; finance; and the transfer of control from the military to civilian organizations. ${ }^{58}$ In his comments on finance, Price noted:

The deep financial crisis through which the Chinese government has been and still is passing has made extremely difficult up to now the support of even modest emergency relief programs. Adequate preparation for relief and rehabilitation now calls, however, for very substantial outlays... Will the Chinese government be able to provide funds for the essential relief and rehabilitation goods and services until the importation of UNRRA supplies in quantity is possible? ${ }^{59}$

There was a request for “essential overall coordination” with relief and rehabilitation as the "primary objective of the government." The medical crisis revealed by the end of the

\footnotetext{
${ }^{57}$ UNA S-0528-0053 (China weekly reports, 1944-45), report by Price, UNRRA China Office, “Immediate problems of relief and rehabilitation,” 23 Aug. 1945, 1.

58 Price, “Immediate problems," 1-10.

${ }^{59}$ Price, "Immediate problems,” 8-9.
} 
fighting led Price to request “comprehensive planning” for hospitals and epidemic treatment. Price’s report declared that UNRRA regarded this as an “emergency programme of great value" because the agency needed information that would be of use when "larger areas are liberated.” 60 The programme was also considered “an excellent means of training personnel for the bigger job ahead and in providing a basis for realistic planning.”61

One survey by UNRRA officers Raymond T. Moyer and Mildred Bonnell involved a trip of some 550 miles across central and western Henan, one of the worst-affected areas. They interviewed local officials and missionaries as well as personally inspecting areas in need. They estimated that the population of the area affected was around 12 million persons, with “conservatively approximately 2,000,000 persons... already in desperate need of relief.” In the western part of the province, they estimated that there was sufficient assistance for only 30 per cent of the population, whereas "without outside assistance the rest are faced with slow starvation and serious exposure... The situation in the greater part of the other affected areas may not be as desperate, but still very serious.” Conditions had been badly affected by the fighting in early 1945, when clashes between Japanese and National Government troops led to mass refugee flight, and the destruction of homes and businesses in the area. Silk production had been important in this region, and "a great deal of this industry was wiped out," removing an important source of local employment. ${ }^{62}$ They calculated the numbers “without food and clothing” at 500,000, the number of buildings destroyed at 100,000 and work animals lost at 140,000. Overall, they declared, "If measures for rehabilitation are undertaken at the same time relief is given, the population can achieve some measure of

\footnotetext{
${ }^{60}$ Price, "Immediate problems," 8.

${ }^{61}$ UNA S-0528-0053 (China weekly reports, 1944-45), report by William J. Green, "Food Production in Liberated Areas in Kweichow and Kwangsi Province,” (25 June 1945), 11.

62 UNA S-0528-0058 (Honan, 1944-49), famine report by Raymond T. Moyer and Mildred Bonnell (3 Nov. to 6 Dec. 1945).
} 
stability by fall."63 They went on to comment that "we found everywhere an enormous interest in the problems of relief and rehabilitation,” with some areas setting relief committees with "honest and efficient personnel," whereas others were "not followed up with an effective organization.” However, "almost every magistrate has it [relief and rehabilitation] as a major worry.”64

Authority, violence and variable geography of violence

UNRRA's observers and Jiang Tingfu shared an understanding of the fragile situation of postwar China. In summer 1945, the state had rapidly to take on a new, chaotic and expensive set of responsibilities in areas that had spent most of the war either under occupation or on the frontline.

One consequence of the war had been a clear breakdown in what Prasenjit Duara has called the "traditional nexus of power." 65 This nexus had already come under severe pressure during the Nanjing decade, but was subject to yet further pressures after the outbreak of war with Japan in 1937 because of refugee flight and the destruction of much of the traditional land and landholding patterns. Local patterns of development could recover after an initial Japanese occupation, as Toby Lincoln has shown for the Wuxi area, but the Yangtze delta benefited from the fact that it was not subjected to severe conflict after the initial phase of the war in 1937-38, unlike much of central China. In Chongqing and Sichuan, as seen above, there was sufficient stability to attempt a social welfare/hygiene-oriented programme of

\footnotetext{
${ }^{63}$ Moyer and Bonnell report.

${ }^{64}$ Moyer and Bonnell report.

${ }^{65}$ Prasenjit Duara, Culture, Power and the State; Rural North China, 1900-1942 (Stanford, 1988).
} 
rehabilitation. In the Yan'an base area too, there were significant and far-reaching social reforms. ${ }^{66}$

However, there was less stability in parts of China where there were multiple, and shifting sources of authority. In many occupied areas, Japanese control was limited to zones close to the railway lines or major cities, with the countryside much harder for them or their collaborators to penetrate. Furthermore, significant parts of China were subjected to experiences during the wartime period that weakened local control or even eliminated it. The flooding of central China after the Yellow River dikes were breached in June 1938 had catastrophic effects on local governmental structures. This area, along with a much wider tranche of central China, was once again subject to major disruption during the Ichigo campaign, as well as subsequent campaigns in 1945. These created huge disruption in areas where authority was already weak. Postwar China was marked by a very variable sense of state capacity to use coercion, and widespread violence by non-state actors.

The relationship between statemaking, state breakdown and refugee flight in the late 1940s has been explored in some detail in the context of the partition of India as well as the transitions in Eastern Europe. The refugee flight that accompanied Partition was a product of a nationalist project that led to the division of a pre-existing but increasingly fractious geobody. In Eastern Europe, hastily constructed geobodies (such as the Nazi Generalgouvernment that occupied territory previously belonging to pre-war Poland) were being deconstructed swiftly or plunging into their own civil wars (as in the conflict nearcontemporaneous with the Chinese one, the Greek Civil War of 1946-49). In China, the sudden end of the war in 1945 saw the collapse of the Japanese occupation. In some areas,

\footnotetext{
${ }^{66}$ On disruption, see Micah S. Muscolino, The Ecology of War in China: Henan Province, the Yellow River, and Beyond, 1938-1950; on partial reconstruction, see Toby Lincoln, Urbanizing China in War and Peace: The Case of Wuxi County (Honolulu, 2015).
} 
Japanese administrators were instructed to stay on, as the returning Nationalists tried to avoid the Communists filling the void. However, the continued conflict over authority, created a reality of violence and disruption on the ground in large parts of China, which would soon become a civil war.

The disruption affected all parts of China, but the aftermath was particularly notable in areas which had suffered major military and environmental disruption during the war years itself. This reality is reflected in the frequent violent responses seen to the attempts by UNRRA and CNNRA survey groups attempting to gather information for reconstruction. One famine team, moving around the Hengyang area, encountered violence on a regular basis. In Leiyang, a town of some 30,000 people, where there was very little food for sale: ... the people were very restless and angry. They kept milling about, shouting and quarreling. [sic] As we walked among them, they crowded about us to such an extent that the officials [... and] a few soldiers had to push and shove them away and some were struck across the face and head. They would grab at us, try to get close and would throw themselves down in the road in front of us, crying for food. ${ }^{67}$

As the team left, their car was mobbed by the locals. They estimated the numbers as around 1500 in total, a “frightening and disheartening experience” that ended only when soldiers with pistols forced the crowd to release the visitors' car. In this area, the local magistrate "said he was convinced that there was no hoarding." 68 In the Lingling area of Hunan, surveyor Vera McCord wrote of a “mob spirit” and a “near riot” as hungry children climbed into their vehicles, demanding food. ${ }^{69}$ Essentially, foreigners needed military

\footnotetext{
${ }^{67}$ UNA S-0528-0009 (Famine surveys), report by Harold Matthews, “Observations and experiences on Highway from Hengyang to Leiyang,” (1946, n.d.) 2-3.

${ }^{68}$ Matthews, “Observations,” 3.

${ }^{69}$ UNA S-0528-0009 (Famine surveys), report by Vera McCord, "Welfare survey: Ling-ling area, Hunan province” (1946, n.d.), 2.
} 
protection to travel around because of the fear of riots. One discussion of the methodology of the nutrition surveys made it clear that certain areas of Hunan would be selected because of "the conditions of transportation" and "safety of those places," these factors being listed ahead of "the severity of the famine," even though places lacking in the first two might easily be worse off when it came to the third. ${ }^{70}$

More direct political confrontation also became a factor. In a letter to UNRRA China director Glen Edgerton on 10 December 1946, UNRRA’s chief Regional Representative Harald H. Lund complained about the searching of CNRRA trucks by the CCP. He noted that many of the drivers for CNRRA might previously have driven Nationalist soldiers, meaning that caution was necessary when in territory where Nationalist and Communist jurisdictions might clash. There is a "lack of mature and well-qualified people to manage the CNRRA teams in Communist territory," he observed, and it would be "not wise” to send supplies to a Nationalist-held city without some also being sent to surrounding CCP-held territory. ${ }^{71}$

In North China, in areas where the CCP had a strong presence, violent encounters took place on a regular basis. In some cases, as when a relief convoy was hijacked between Beiping and Chengde in late November 1946, the issue was quickly resolved, with the CCP admitting it was a “mistake” and paying $\mathrm{CN} \$ 300,000$ in compensation. ${ }^{72}$ However, relations began to break down as the Nationalists tried to use CNRRA convoys as a means of attacking the CCP-controlled areas, and both sides started to use access to food and supplies as political leverage. By the end of the UNRRA programme, the CCP was clear in its negative view of the agency:

\footnotetext{
${ }^{70}$ UNA S-0528-0009 (Famine surveys), report by C. F. Wang, Enid Fisher, Anne Huizenga, "Nutrition survey, Hengyang-Lingling region” (1946, n.d.), 1.

${ }^{71}$ UNA S-0528-0032 “Taiyuanfu-Shansi: confidential” (10 Dec. 1946), Lund to Edgerton.

72 UNA S-0528-0032, (cable, Grant to UNRRA Shanghai, 27 Nov. 1946).
} 
No matter how UNRRA decorates itself, people of the whole world have never been so aware, as at the present time that UNRRA has degenerated from an international relief organization to an instrument of the American State Department, and its China Office is a war supply agent for the Nationalist Government."73

The underlying violence of the immediate postwar had merged with the incipient Civil War, rendering attempts at reconstruction immeasurably harder.

\section{Malnutrition}

UNRRA was a successor to prewar networks of knowledge that concentrated on issues of rural rehabilitation in Asia, operated through the League of Nations. Sunil Amrith and Patricia Clavin have shown how the League of Nations drew on the experience of rural rehabilitation in Eastern Europe to promote ideas of “development” in Asia in the prewar years. In this vision, the desire by western reformers (largely drawing on British imperial experience) to try and control issues such as malnutrition and disease through technological change, combined with the visions of Asian nationalists who advocated national planning as a way of dealing with a potential crisis of food security. ${ }^{74}$ In August 1937, a conference on Rural Hygiene was held under League auspices in Bandung, in the Netherlands East Indies, at a time when in the words of one League official, “in each country, 'rural reconstruction' is prominent in the papers, and is on everyone's lips.” India, Japan, Siam, the Philippines, and China were among the countries represented; but the latter was already in the first weeks of the Sino-Japanese conflict that would destroy much of China's state capacity. ${ }^{75}$ In 1945 ,

\footnotetext{
${ }^{73}$ UNRRA relief for the Chinese People: A Report by CLARA (Shanghai: Information Office of the Chinese Liberated Areas Relief Association, 1947), 1.

${ }^{74}$ Sunil Amrith and Patricia Clavin, "Feeding the world: connecting Europe and Asia," Past and Present 2013 (suppl. 8), 38.

${ }^{75}$ Amrith and Clavin, "Feeding,” 46.
} 
Jiang Tingfu and his collaborators would attempt to pick up the process of internationalization that had had to be downplayed, if not abandoned, in the face of war.

The desperate lack of food in significant parts of China was the most pressing theme to occupy UNRRA and CNRRA in the immediate aftermath of the war, with areas of Henan, Shanxi, Shandong, Jiangsu, Fujian, Hunan, Guangxi, Guizhou and Anhui provinces particularly affected. ${ }^{76}$ UNRRA estimated that some 6.76 million Chinese were in "critical need” in April 1946, and some 32.8 million in need of supplementary food. "The needs of these areas alone far exceeded the relief resources provided to China by UNRRA,” noted the official history, “particularly in 1946."77

The UNRRA Welfare Survey team visited the refugee camps in Hengyang, Hunan province, in June $1946 .^{78}$ The atmosphere was still of widespread chaos, nearly a year after the war with Japan had ended. The Hengyang area had been at the centre of one of the most hard-fought campaigns of the Ichigo campaign. Refugee flight combined with chaotic bureaucracy led to major obstacles in bringing effective relief to the city. The mayor had spoken of the difficulties caused by the increase in the population from 150,000 to 200,000 , of whom some 90,000 were said urgently to need food. One camp (no. 5) visited by the team housed some 600 people in tents that provided little protection against the heat, all of whom were in a state of advanced malnutrition. Supplies were often unusable; a delivery of flour could not be used because there was no cooking equipment there. Promised supplies of milk were not being delivered. There was a “complete breakdown” in coordination between officials, with a death rate "on the streets" of around thirty a day. Other reports from the area

\footnotetext{
${ }^{76}$ Woodbridge, UNRRA, 386-7.

${ }^{77}$ Woodbridge, UNRRA, 406.

${ }^{78}$ UNA S-0528-0009 (Famine surveys), report by Enid Fisher, "Welfare survey, Hengyang area, Hunan province” (1946?).
} 
spoke the camps being as bad as Belsen, or worse than during the famines in wartime India, with "horrible physical collapse" frequent. ${ }^{79}$

Two surveys of areas in Hunan province allow us to understand details of the levels of devastation suffered in the parts of China most affected during the Ichigo campaign.

UNRRA surveyors visited Hengyang and Lingling counties in 1945-6, largely before the civil war started to break out, finding conditions of intense need. Vera McCord, the leader of the Famine Survey Team in Lingling, estimated that some 158,000 of the total 528,000 population in the region were in need of relief. Based on an extensive set of interviews with local officials and ordinary people, UNRRA contacts and missionaries, she noted that there was an urgent need for medical care, and further, that there was no sign of hoarding. She also noted the danger of a poor harvest in 1947, and that assistance to farmers was a top priority. In Lingling’s villages, some 15 to 180 li from Lingling city, there were reports of beri-beri and malaria. "There appeared to be a decrease in the birth rate,” McCord reported. ${ }^{80}$

Networks of supply were a major problem in the region. Deliveries of flour were insufficient in amount, and being sent in a form that left the powder hard and caked. People were eating clay that caused bowel obstructions. Jiang's plan had given priority to using supplies to recreate China’s economic infrastructure; but McCord saw the level of desperation and wondered whether more of the flour available should be used to relieve simple destitution, rather than being saved to pay for work relief schemes. ${ }^{81}$

Another survey in the same district examined five villages within the same HengyangLingling area. Overall, the survey demonstrated “extremely poor” levels of nutrition in the county; local diets included "grass, wheat husks, rice polishing, wheat bran and legumes” as

\footnotetext{
${ }^{79}$ Fisher, "Welfare survey”; Matthews, "Welfare survey."

${ }^{80}$ McCord, "Welfare survey."

${ }^{81}$ McCord, "Welfare survey."
} 
standard. Despite milk and beef being supplied by CNRRA, with rice from the county government, the five doctors who signed off the report warned that significant numbers of locals were on the "border line of death." 82

While Hengyang was clearly in crisis, it was by no means the only such area. Moyer and Bonnell's visit to western Henan in November and December 1945 noted the effects of a variety of factors, including flooding, the Japanese occupation, and depredations by the Chinese military, who had fought major battles there in spring and summer 1945. The region had a population of some 12 million of whom 2 million were in "desperate need.” The local silk industry had been devastated, and the Japanese had transported immense amounts of grain away from the region. Epidemics were rife, and only some 30 per cent of the population could be assisted with locally-supplied resources. The surveyors noted that the returning refugees had also brought disease with them, and that some 80-90 per cent of the population had become ill between their return and the UNRRA survey visit. In the worst-affected areas, the mortality rate reached some 15 per cent. ${ }^{83}$ Overall, the sentiments of the surveyors were summed up in two contrasting statements: that "the problems in western Honan illustrate beautifully the genius of the conception of relief and rehabilitation,” and that “people need everything." 84

\section{The UNRRA crisis}

By 1946, UNRRA and CNRRA's cooperation was coming under major strain. The financial structure of the programme generated increasing problems. China was permitted to sell a proportion of the UNRRA material to bring in government income, but because the

\footnotetext{
${ }^{82}$ Fisher et al., "Welfare survey," 1.

${ }^{83}$ Moyer and Bonnell, Report, 1-2.

${ }^{84}$ Moyer and Bonnell, 2.
} 
currency was not stable, shipping costs to the interior continued to rise and ended up as a major burden on CNRRA (see above). This forced CNRRA to take on a major loan from the Central Bank, which in turn reduced CNRRA’s standing within the Executive Yuan, as well as reducing the credibility of Jiang's arguments that the agency could serve as a force for a progressive reconstruction. ${ }^{85}$

Events came to a head in June 1946, when reports were received in the United States that shipments of material were piling up in Shanghai harbour, leading the director of UNRRA, former New York mayor Fiorello LaGuardia, to place a ban on any further shipments to China. In July 1946, Jiang gave an angry press conference, reported by the Shenbao newspaper, which hit back at criticisms of his agency. He pointed out that eight years of war had "almost completely destroyed water and rail transportation networks," leading to inevitable bottlenecks. He argued that the situation had improved, and that of nearly 560,000 tonnes of UNRRA material that had been delivered by March 1946, all but 79,000 tonnes had been transported by June. Jiang argued also that he had had a successful engagement with the CLARA areas, and that it was a "misunderstanding” that only 2 per cent of the UNRRA material made it to the CCP-controlled areas, also arguing that material such as “jeeps, railway and steamship equipment, river defence material, etc.” was not for general distribution. He also claimed that while 80 per cent of the UNRRA material was grain, "most of the Communist areas have had a strong grain harvest. When we distribute material, we must do it on the basis of need." 86 Jiang continued to defend CNRRA's record in later articles. In September 1946, in his last month in office, he argued that the separation of obligations between UNRRA and CNRRA had led to serious financial problems: "From the

\footnotetext{
85 Zhang, Jiang Tingfu, 255.

${ }^{86}$ Shenbao (12 July 1946), cited in Zhang, Jiang Tingfu, 257.
} 
end of June to the beginning of July, CNRRA had no money. During this period, the government didn’t provide any expenses and the banks would not give us a loan.”"87

Clearly Jiang was seeking to justify the performance of the agency which he headed. However, UNRRA’s own assessment of the China programme, shortly after its conclusion, was positive in significant part. Accounting for errors, "the actual proportion of UNRRA food which... did not reach the intended recipients was perhaps 10-15 per cent,” with about the same amount being poorly distributed. "The remaining 70-80 per cent, it is believed, went to participants in real need, and it certain that the distribution effected in deficit areas relieved acute shortages for the population as a whole in those areas.” On work relief programmes, “at the end of October 1947 it was estimated that through UNRRA-supported flood-control, irrigation, and drainage projects about 4,366,000 acres of land had been reclaimed, while several times that amount had been protected against flooding by dike construction and repair work.” They assessed that some 2-3 million people had been rescued from starvation, and 810 million (including 1 million refugees) "given some assistance” as they returned home. Over two million were given “employment in UNRRA-supported work projects”which helped restore "several thousand miles” of highways and railway roadbeds; sanitation, dredging, construction; revival of local industries; "restoring to production more than four million acres of land and affording added protection to about thirty million acres.” Over \$71 million of agricultural rehabilitation supplies were significant in "restoring China’s indigenous food output to approximately its prewar level.” Rehabilitation had had significant successes: annual food production from reclaimed land would be "four times the total amount of food provided to China by UNRRA and about thirty-seven times the amount of UNRRA food used in support of those projects.” It concluded: “These were among the positive benefits to the people of China jointly attained, in spite of all difficulties and shortcomings,

${ }^{87}$ Zhang, Jiang Tingfu, 258. 
through the largest program of internationally sponsored assistance ever developed on behalf of a single nation. How much more extensive and enduring the results might have been, but for the continuing dislocation and destruction resulting from civil war, must be left to conjecture.”88

UNRRA itself was a troubled institution in many ways, and its early demise owed perhaps more to the problems it encountered in Europe as to those in China. In some ways, UNRRA was the inheritor of the colonial framework that had shaped the League of Nations, and aspects of that colonial mindset grated on the Chinese. In Europe, UNRRA had to deal essentially with conquered or liberated peoples. In China, it had to negotiate with a country as devastated as any in Europe, but also a sovereign ally, with all of the touchiness on both sides that the situation implied. In addition, the incipient Civil War created huge uncertainties and made peacetime rehabilitation immeasurably harder.

However, perhaps the single most important, and retrospectively underappreciated, reason for the mismatch between aspiration and achievement in the UNRRA/CNRRA project was the sheer scale of the task. As the data above has shown, the scale of destruction was huge and the resources to combat that destruction relatively small in comparison. However, the failure of the project should not obscure the importance of the ideas that Jiang was seeking to implement through a joint UNRRA/CNRRA project, which was most concerned not just with immediate relief, but the continuation and expansion of a pre-existing modernizing project interrupted in 1937.

Writing in 1947, shortly after the end of the UNRRA programme, Jiang proposed an argument that seemed to have the aura of Bretton Woods and the idea of economic

${ }^{88}$ Woodbridge, UNRRA, 409, 412, 452-3. 
interdependence, perhaps gathered from figures such as Sun Fo who had attended the meeting ${ }^{89}$ :

Modern scholars of economics have become more optimistic overall about the future of the world economy. They feel that with modern science, the production capacity and standards of living of the whole world can be greatly raised. They believe that one country's poverty leads directly to disaster in other countries. To put it the other way, one country’s prosperity can directly affect the benefit felt by another country. Economically, this is a world of mutual coexistence and mutual prosperity. If every country’s foreign policy was decided by economic factors, international cooperation would be smoothly realized. ${ }^{90}$

There is a poignancy, along with an unreality, about the "if” in Jiang's last sentence. Jiang continued to make the case, as late as 1949, for the Nationalist government as potential reformers. During his January 1949 Washington speech, he argued that the aim of the Nationalist government was to mandate rent reductions for tenant farmers from 50 to 33 per cent of the produce from the land: "that has been the law of China for the last three years." However, he acknowledged that there had been little action on land reform under the Nationalists, and that further action was needed in a variety of other areas: "better seeds, better and more fertilizers, better irrigation, better marketing facilities, and better processing machinery.”91 He argued that the Central Agricultural Research Institute had done work before the war that produced increases in rice and grain productivity of eleven to thirteen per cent; that they had imported cotton seeds from the US; and that they had improved flawed irrigation. "What the present government has done, however, has not been enough. It should

\footnotetext{
${ }^{89}$ Eric Helleiner, Forgotten Foundations of Bretton Woods; International Development and the Making of the Postwar Order (Ithaca, 2014).

${ }^{90}$ Jiang, Mantan zhishifenzi, JTF, 674.

${ }^{91}$ Jiang, “Situation,” 508.
} 
have done more. It could have done more. It is not true, however, that the Government is blind to the needs of the peasantry or that the ruling class of China during recent years has been dominated by the class interests of the landlords." 92 By January 1949, when he made this speech, this pleading was far too late.

Why, then, should we treat it as anything more than the last, poignant thoughts of a liberal voice that was about to overwhelmed by a politics radical beyond anything he had yet imagined in China? The answer is that the nature of the task undertaken by Jiang and the CNRRA authorities helps us rethink a common and understandable narrative of the immediate postwar in China. The rise to power of the CCP is often portrayed as the inexorable rise of a military machine, allied to a social programme, of an organization that definitely defeated a failed and venal opponent. Clearly, there is a great deal to support this interpretation.

Hewing to it exclusively, however, obscures a context that helps to explain the structure of the postwar world more clearly. The Communists and Nationalists did not operate in isolation from one another; they were clearly in competition, and Jiang's mixture of Marxist-influenced social thought combined with his increasingly strong anti-communism (in contrast, say, with his fellow-technocrat Weng Wenhao, who eventually gave his loyalty to the People's Republic of China) showed that he understood the need for a progressive, modernizing (rather than "feudal” or "reactionary") postwar reconstruction, and hoped to use the UNRRA/CNRRA programme to help achieve it. The civil war of ideas in China was not simply between and old regime and a new, but between different visions of the postwar. Jiang Tingfu's model was clearly traceable to the modernization that had occurred in pre1937 China, about which he had been one of the most eloquent writers, as were the postwar

\footnotetext{
92 Jiang, “Situation,” 508.
} 
models of other Allied nations. Yet it was also shaped by the experience of war itself, and in particular the range of social reform and hygiene programmes that emerged during those years, as well as China's experience of being a postcolonial, as well as postwar state.

The CNRRA programme was, very explicitly, a form of postwar modernization that W. W. Rostow would later recognize, all the way down to the idea of a "traditional society" needing a "takeoff." The Nationalist project in the postwar could be seen as a deeply flawed and ultimately failed form of developmental state, not simply a "feudal” regime that collapsed under the weight of its own contradictions. Jiang's attempts to use UNRRA to promote rehabilitation in postwar China need to be considered as a starting point for a longer history of the way in which postwar Asian societies used development as a site for contestation over modernization. China was treated by the international community as a significant state which had a certain level of agency to act and make political choices, in contrast with Japan, the reconstruction of which took place under American occupation, or the authoritarian developmentalism of Syngman Rhee in South Korea which took place in the aftermath of a failed attempt at UN trusteeship. China’s membership in ECAFE was one visible part of that integration as a sovereign state into a new international order in Asia, although its role would be fundamentally altered by its loss of the civil war in 1949 .

In his October 1949 speech, Jiang declared: “China’s basic problem is poverty, and the chief solution is economic development.”93 In 1950, after the regime had fallen to the mainland, Jiang maintained his view that China’s development was part of a longer trajectory toward democracy and economic development, and that it was part of a wider Asian trend:

\footnotetext{
93 Jiang, “Problems,” 537.
} 
I have been connected to the National Government for the last fifteen years. If I were to criticize my own Government, I think I could do it much more to the point than some of the criticisms I have read in your publications. However... the National Government of China serves much better as the starting point for the modernization of China than the Communist regime at Peiping. After all China's fundamental problem is modernization. By modernization I include both democratization and economic development. So far as this is concerned, the other countries of Asia face the same fundamental problem of modernization.

The draft notes for this speech declared that other governments in Asia would “severely try [US] patience.” In the original draft, there is a line reading “At such times, you will look back upon your experience in China and will say to yourselves that your work in China had met with a measure of governmental and popular cooperation far exceeding what you meet with now." 94 The line is scored out, suggesting that it did not make it to the final delivered version of the speech. In the deleted line, however, one can read Jiang's resentment that his attempt to make the UNRRA/CNRRA cooperation a building block for a sovereign China, allied to the US, and an example to Asia more widely, might seem more prophetic in retrospect than it did at the time.

${ }^{94}$ Jiang, “The Asian Half of the World” (speech at University of Washington, 16 Feb. 1950), MHD vol. $21,544$. 